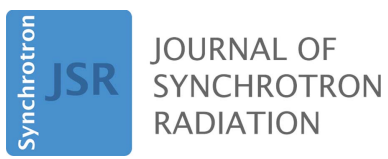

ISSN 1600-5775

Received 24 January 2019

Accepted 19 April 2019

Edited by R. W. Strange, University of Essex, UK

Keywords: zinc standards; Zn K-edge; XANES; spectroscopy.

Supporting information: this article has supporting information at journals.iucr.org/s

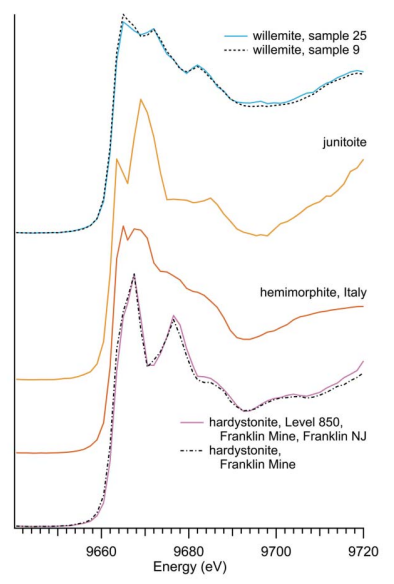

OPEN $\odot$ ACCESS

\section{Zinc $K$-edge XANES spectroscopy of mineral and organic standards}

\author{
Erin K. Griffith, ${ }^{a}$ Ellery D. Ingall, ${ }^{\mathrm{a} *}$ Peter L. Morton, ${ }^{\mathrm{b}}$ David A. Tavakolic and \\ Barry Lai ${ }^{\mathbf{d}}$
}

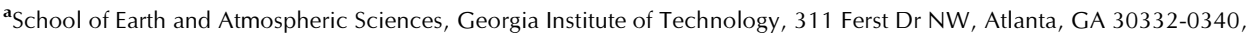
USA, 'beochemistry, National High Magnetic Field Laboratory, 1800 E Paul Dirac Dr, Tallahassee, FL 32310, USA, ${ }^{c}$ Materials Characterization Facility, Georgia Institute of Technology, 345 Ferst Dr NW, Atlanta, GA 30332-1000, USA, and ${ }^{\mathbf{d}}$ Advanced Photon Source, Argonne National Laboratory, 9700 South Cass Avenue, Argonne, IL 60439, USA. *Correspondence e-mail: ellery.ingall@eas.gatech.edu
\end{abstract}

Zinc $K$-edge X-ray absorption near-edge (XANES) spectroscopy was conducted on 40 zinc mineral samples and organic compounds. The $K$-edge position varied from 9660.5 to $9666.0 \mathrm{eV}$ and a variety of distinctive peaks at higher post-edge energies were exhibited by the materials. Zinc is in the +2 oxidation state in all analyzed materials, thus the variations in edge position and post-edge features reflect changes in zinc coordination. For some minerals, multiple specimens from different localities as well as pure forms from chemical supply companies were examined. These specimens had nearly identical $K$-edge and post-edge peak positions with only minor variation in the intensity of the post-edge peaks. This suggests that typical compositional variations in natural materials do not strongly affect spectral characteristics. Organic zinc compounds also exhibited a range of edge positions and post-edge features; however, organic compounds with similar zinc coordination structures had nearly identical spectra. Zinc XANES spectral patterns will allow identification of unknown zinc-containing minerals and organic phases in future studies.

\section{Introduction}

Zinc $K$-edge X-ray absorption near-edge spectroscopy (XANES) is a valuable tool for determining the solid-phase chemical speciation of zinc across a wide range of disciplines and applications. Agriculturally, research includes using zinc to enhance the grain concentration of plants (Doolette et al., 2018) and using colloidal particles to increase the rate of discharge of zinc and phosphorus from swine manure used as a fertilizer (Yamamoto \& Hashimoto, 2017). Industrial studies have looked at the speciation of zinc in a fly ash spill (Rivera $e t$ al., 2017) and steelmaking sludge (Wang et al., 2013). Environmentally, there has been research into heavy metals in combined sewer overflow discharge (Rouff et al., 2013) and organic waste amended soil as fertilizer (Tella et al., 2016; Mamindy-Pajany et al., 2014). Because XANES measures structural composition, other research has included multiple nanotechnology studies (Zhou et al., 2017; Frenkel et al., 2001). However, research is not limited to environmental and industrial applications, as zinc $K$-edge XANES has also been used to analyze the paint in historic paintings, without degrading the pigments (Gervais et al., 2015).

Zinc, as a bioactive trace metal, is a vital nutrient for all living organisms, yet can also be toxic at high concentrations. The chemical form of zinc can be a key factor in determining its potential bioavailability or toxicity to organisms. In turn, zinc bioavailability has implications for the health and 
productivity of riverine (Le Pape et al., 2014), terrestrial (Isaure et al., 2005; Webb \& Gaillard, 2015; Manceau et al., 2002; Sarret et al., 2004) and marine systems (Löscher, 1999). In marine environments, zinc is a component of two enzymes carbonic anhydrase and alkaline phosphatase (Sunda \& Huntsman, 2005). These enzymes are critical for the growth of most planktonic organisms serving as primary producers at the base of the food chain. In marine diatoms, which account for $20 \%$ of total global primary productivity (Malviya et al., 2016), zinc is vital in the growth of their hard silica exoskeleton (Ellwood \& Hunter, 2000).

A common approach in the study of elemental cycling within natural systems is to fit XANES spectra of unknown samples with spectra of known, well characterized materials (Leinweber et al., 2007; Gaur et al., 2009; Gräfe et al., 2014; Da Silva-Cadoux et al., 2012; Oakes et al., 2012; Longo et al., 2014). For many elemental systems, including zinc, comprehensive databases of XANES spectra are not available, which makes it more difficult to interpret spectra of unknown materials. Although plots of Zn-XANES spectra for standards of a limited number of materials may appear in studies, such as the ones listed above, the data for these spectra is typically not provided. Some previous zinc spectroscopy studies focused on standards created for EXAFS at a temperature of $20 \mathrm{~K}$ (Jacquat et al., 2009), but a large, comprehensive set of zinc $K$-edge XANES, which would be especially relevant for measurements under environmental conditions (Monsant et al., 2011), does not appear to currently exist.

The breadth of zinc standards that can be analyzed concurrently with the research being conducted is often limited by scheduling constraints. As a result, many studies must rely on a small sample set of zinc standards which is then used to inform the XANES analysis of the focus of the research (Cheng et al., 2018; Wang et al., 2007; Dessombz et al., 2013; Adediran et al., 2015). The zinc standard references presented here (Table S1 of the supporting information) will provide researchers with a diverse spectra database to initiate studies of zinc mineral speciation, thereby saving valuable synchrotron time for sample analyses. These references include both natural and synthetic materials, which will be useful in characterizing the mineral speciation of zinc in natural and anthropogenically impacted settings.

\section{Methods}

Zinc spectroscopy was run on 34 different mineral or inorganic phases and six zinc-containing organic phases. Multiple samples of some of the naturally occurring minerals were measured to evaluate the effects of compositional variations within one mineral species. The samples were either in private collections or were obtained from mineral dealers or chemical supply companies. The identity of all minerals, with the exception of one hetaerolite sample with insufficient sample mass, was verified with powder X-ray diffraction (XRD) at the Georgia Institute of Technology.

The zinc materials were measured at the 2-ID-D beamline at the Advanced Photon Source synchrotron at Argonne
National Laboratories in Illinois, USA. This beamline has an energy range of $5-30 \mathrm{keV}$ and a focused flux of $4 \times 10^{9}$ photons s$^{-1}$ at $10 \mathrm{keV}$ which makes it ideal for highresolution X-ray imaging (Ingall et al., 2018). The source of the beamline is a $3.3 \mathrm{~cm}$-period undulator, and a Kohzu Si (111) monochromator was used to provide an energy resolution of $1.4 \times 10^{-4} \Delta E / E$. The energy was calibrated at $9659 \mathrm{eV}$ using the inflection point of the $K$-edge of a zinc metal foil standard material. The samples were ground to a fine powder $(<10 \mu \mathrm{m})$ to minimize self-absorption. Comparing the fluorescence with the transmission data confirms that the samples were sufficiently thin to avoid self-absorption in accordance with previously accepted methods (Waychunas et al., 2003). Less than $1 \mathrm{mg}$ of powder was distributed over approximately $1 \mathrm{~cm}^{2}$ of cellulose acetate membrane which was then placed over a slot on an aluminium mounting stick. For these experiments, the undulator was tuned to $9.68 \mathrm{keV}$ and the energy scan was conducted in $0.5 \mathrm{eV}$ steps between 9.64 and $9.72 \mathrm{keV}$ while the $\mathrm{X}$-ray fluorescence signal was collected by a silicon drift detector (Vortex-EM).

Using the fluorescence signal, the Zn-NEXFS (zinc nearedge X-ray fluorescence spectroscopy) data were collected. Zn-NEXFS differs from Zn-XANES in the signal detection, in that it uses the fluorescence signal to obtain an absorption signal which is inversely proportional to the XANES signal. The fluorescence detector only measures the signal from the interactions of the beam with the zinc atoms. In contrast, in the ion chamber used for XANES measurements an extremely small percentage of the incoming radiation reaching the ion chamber is absorbed by $\mathrm{Zn}$ atoms. Thus the absorption signal is extremely small relative to the large amount of radiation reaching the detector. Use of the fluorescence detector allows for a signal with minimal background. This is undoubtedly why fluorescence is the method most frequently employed for natural samples. The samples were analyzed three to five times with a dwell time ranging from 0.5 to $3 \mathrm{~s}$ per step, with higher dwell times given to samples with low concentrations. Care was taken to minimize detector saturation and the dead time $(<10 \%)$, while optimizing the signal, by adjusting the detector position and the size of the slits, in accordance with methods to optimize the quality of analysis conducted using fluorescence in X-ray absorption spectroscopy (XAS) analysis as discussed in the literature (Abe et al., 2018; Gräfe et al., 2014; Waychunas et al., 2003).

The spectra were analyzed with ATHENA XAS data processing software (Demeter 0.9.26 using Ifeffit 1.2.12) (Ravel \& Newville, 2005). The X-ray fluorescence signal was normalized by dividing the zinc counts by the upstream ion chamber counts. Since each sample had been scanned multiple times, these scans were aligned within ATHENA based on the smoothed derivative of energy before merging the absorption edge, with importance placed on larger edge steps, in order to assign higher importance to spectra obtained from a more concentrated sample. Edge-step positions were determined by using the first derivative of the spectra.

All XANES data is provided in Table S1 of the supporting information. 
The identity of the mineral samples was verified on a Malvern PANalytical Empyrean multi-technique $\mathrm{X}$-ray diffractometer and a copper radiation source. Data analysis was conducted with the HighScore Plus software associated with the diffractometer, and a thirdparty database, PDF 4+, from the International Centre for Diffraction Data (ICDD). Each sample was approximately a gram in size and was placed on a silica zero plate to minimize background signals from the sample mount. The masks and slits on the Empyrean X-ray diffractometer were set for the small sample size and each mineral was analyzed for $10-40$ s per step, with a $2 \Theta$ range from $10-90^{\circ}$. Many of the samples were analyzed while spinning at $3.755 \mathrm{rpm}$, to minimize diffraction errors. XRD data are provided in the supporting information.

\section{Results and discussion}

The XANES spectra of all zinc materials in this study had principal $K$-edge peak energies between 9660.5 and $9666.0 \mathrm{eV}$. This peak results from the excitation of an electron from a $1 s$ inner orbital to higher-energy orbitals as a result of interaction with a synchrotron-generated X-ray. Subsequent decay of higher-energy electrons to unoccupied $1 s$ orbitals releases photons, which are counted by the Vortex-EM detector. The minerals and organics measured in this study contained zinc in the + II oxidation state. Although the structural position of

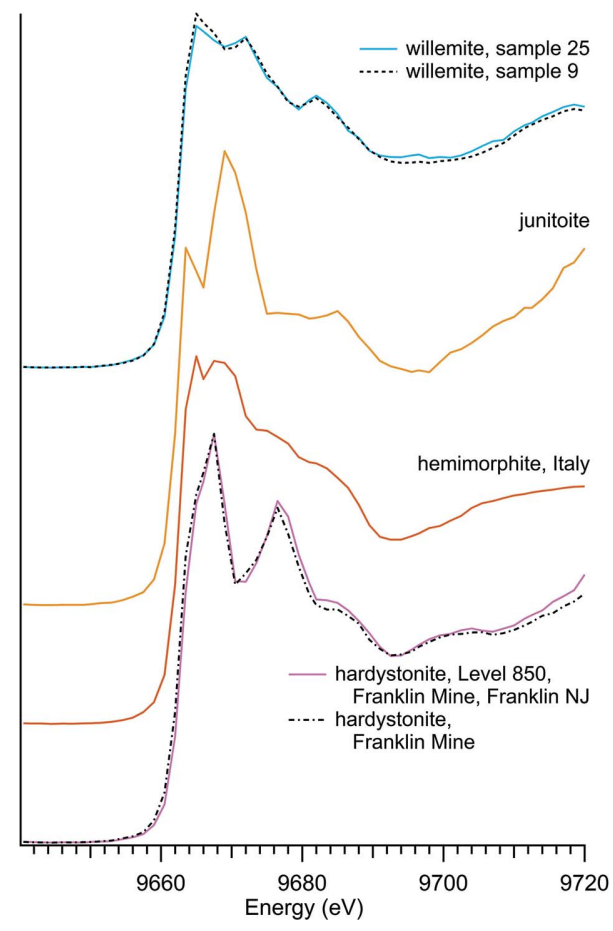

Figure 1

Zinc silicate spectra. zinc within the mineral lattice would be expected to exert a major influence on spectral features, a study investigating the impact of tetrahedral versus octahedral coordination on spectral features shows that these changes are subtle (Waychunas et al., 2003).

Spectra of most minerals also revealed additional pre-edge or post-edge features that can be used to identify specific minerals or differentiate between mineral groups. In general, these pre- and post-edge features are related to (i) the presence and weight percent of different elements; (ii) the oxidation state of these elements; and (iii) the arrangement of these elements in the mineral structure. More information on pre-edge and post-edge features for specific minerals and mineral groups follows.

\subsection{Zinc silicates}

Four unique zinc silicate minerals were studied including three sorosilicates - hardystonite, hemimorphite and junitoite - and one nesosilicate - willemite (Table 1), with spectra shown in Fig. 1. The analysis includes five separate samples of the zinc silicate hemimorphite (Fig. 2), to assess spectroscopic

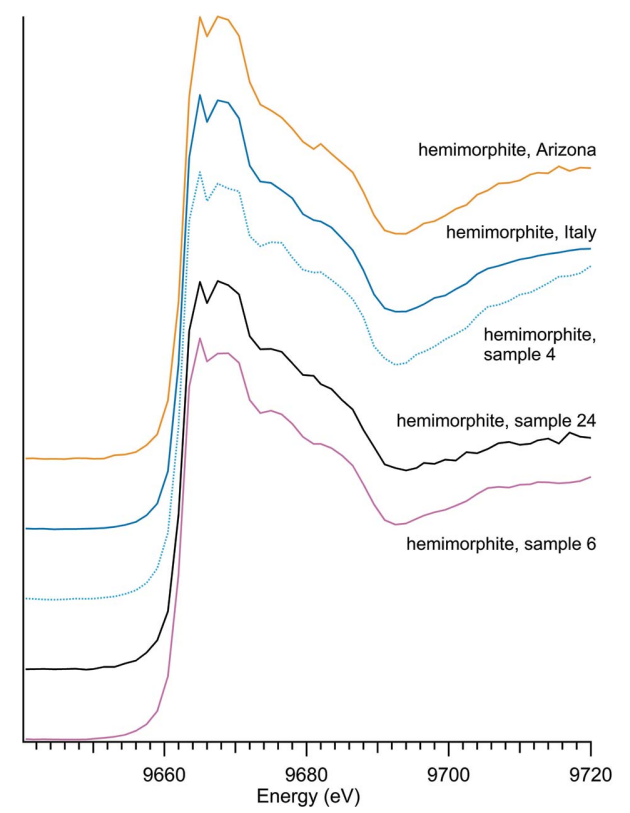

Figure 2

Comparison of hemimorphite minerals. 
Table 2

Zinc carbonates.

\begin{tabular}{lllll}
\hline $\begin{array}{l}\text { Sample } \\
\text { number }\end{array}$ & Name & $\begin{array}{l}\text { Ideal chemical } \\
\text { formula }\end{array}$ & Locality & $E_{0}(\mathrm{eV})$ \\
\hline 41 & Hydrozincite & $\mathrm{Zn}_{5}\left(\mathrm{CO}_{3}\right)_{2}(\mathrm{OH})_{6}$ & Goodsprings, NV, USA & 9663.5 \\
35 & Rosasite & $(\mathrm{Cu}, \mathrm{Zn})_{2}\left(\mathrm{CO}_{3}\right)(\mathrm{OH})_{2}$ & Kelly Mine, Magdalena, NM, USA & 9663.5 \\
26 & Smithsonite & $\mathrm{ZnCO}_{3}$ & Private collection, unknown location & 9666.0 \\
N/A & Zinc carbonate & $\mathrm{Zn}_{5}\left(\mathrm{CO}_{3}\right)_{2} \cdot(\mathrm{OH})_{6}$ & Alfa A14590 & 9663.5 \\
\hline
\end{tabular}

Table 3

Zinc phosphates.

\begin{tabular}{llllc}
\hline $\begin{array}{l}\text { Sample } \\
\text { number }\end{array}$ & Name & $\begin{array}{l}\text { Ideal chemical } \\
\text { formula }\end{array}$ & Locality & $E_{0}(\mathrm{eV})$ \\
\hline 5 & Scholzite & $\mathrm{CaZn}_{2}\left(\mathrm{PO}_{4}\right)_{2} \cdot 2 \mathrm{H}_{2} \mathrm{O}$ & Private collection, unknown location & 9663.5 \\
8 & Tarbuttite & $\mathrm{Zn}_{2}\left(\mathrm{PO}_{4}\right)(\mathrm{OH})$ & Zambia Broken Hill Mine & 9663.5 \\
17 & Zinc phosphate hydrate & $\mathrm{Zn}_{3}\left(\mathrm{PO}_{4}\right) \mathrm{xH}_{2} \mathrm{O}$ & Alfa 11589 & 9663.5 \\
\hline
\end{tabular}

variation across natural samples from different locations. The absorption edge position of $9663.5 \mathrm{eV}$ was the same for all zinc silicates regardless of composition. Zinc silicate spectra all have two distinctive peaks at post-edge energies, the strength of which appears to be unique to this mineral class. Sorosilicate versus nesosilicate arrangement of the $\mathrm{Si}$ tetrahedrons does not appear to be the primary control of spectral features as the three sorosilicates each have post-edge peaks at different energies (junitoite at $9669 \mathrm{eV}$, hardystonite at $9676 \mathrm{eV}$ and a broad hemimorphite secondary peak around $9668 \mathrm{eV})$.

\subsection{Zinc carbonates}

Three natural zinc carbonate minerals - hydrozincite, rosasite and smithsonite - were observed alongside a commercial basic zinc carbonate (Table 2) with spectra shown

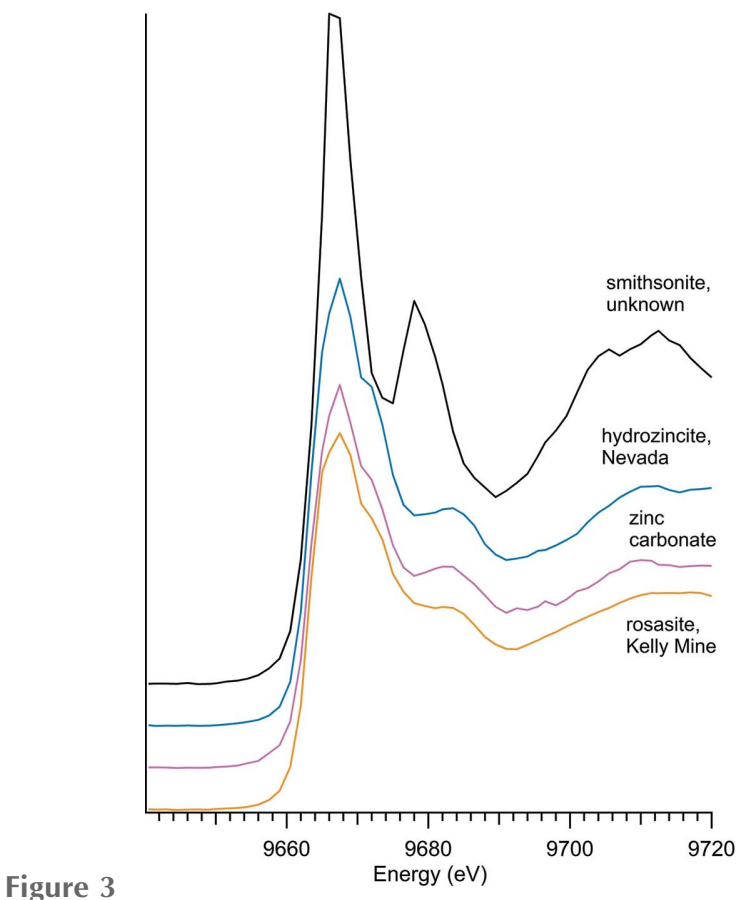

Zinc carbonate spectra. in Fig. 3. The edge positions for the hydrous forms - hydrozincite, rosasite and basic zinc carbonate - are all at $9663.5 \mathrm{eV}$, and the anhydrous smithsonite edge is at $9666.0 \mathrm{eV}$. The spectra of the hydrous zinc carbonates are all characterized by a wider main peak with a prominent shoulder and a higher-energy peak at approximately $9681 \mathrm{eV}$. Smithsonite differs from the hydrous zinc carbonates with a narrower main peak without a prominent shoulder, a very strong higher-energy peak at $9678 \mathrm{eV}$, and a wider peak around $9710 \mathrm{eV}$. These results match well with previous analysis of smithsonite, including those measured in transmission mode (Gao et al., 2014) and in fluorescence mode (Bazin et al., 2009).

\subsection{Zinc phosphates}

Zinc phosphates are distinguishable from the larger selection of oxyanions because of the similarity of their spectra (Fig. 4) and the consistency of the initial $K$-edge peak energy of $9663.5 \mathrm{eV}$ (Table 3). The zinc phosphates contained within this study are the natural minerals scholzite and tarbuttite and a synthetic zinc phosphate hydrate. Zinc phosphate spectra are characterized by a wide main peak which is likely due to the presence of a higher-energy peak at $9670 \mathrm{eV}$. All of the zinc phosphate spectra have a secondary peak at approxi-

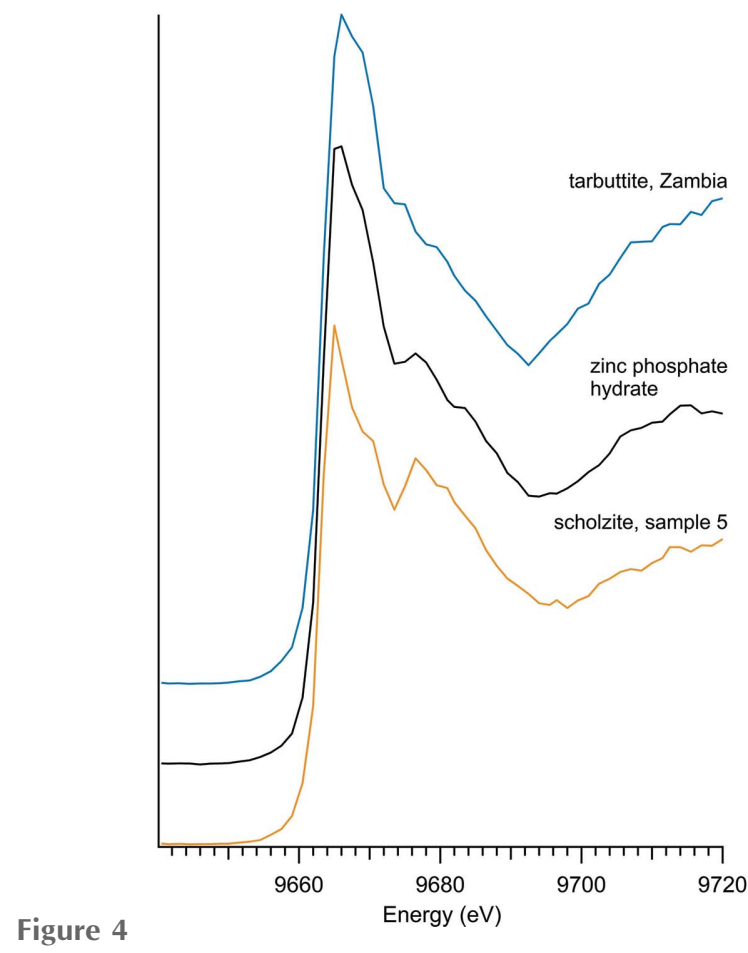

Zinc phosphate spectra. 
Table 4

Additional zinc oxyanions.

\begin{tabular}{|c|c|c|c|c|}
\hline $\begin{array}{l}\text { Sample } \\
\text { number }\end{array}$ & Name & $\begin{array}{l}\text { Ideal chemical } \\
\text { formula }\end{array}$ & Locality & $E_{0}(\mathrm{eV})$ \\
\hline 30 & Adamite & $\mathrm{Zn}_{2}\left(\mathrm{AsO}_{4}\right)(\mathrm{OH})$ & Mina Ojuela, Mapimi, Durango, Mexico & 9663.5 \\
\hline 39 & Adamite & $\mathrm{Zn}_{2}\left(\mathrm{AsO}_{4}\right)(\mathrm{OH})$ & Chihuahua, Mexico & 9663.5 \\
\hline 1 & Ammonium zinc sulfate hydrate & $\left(\mathrm{NH}_{4}\right)_{2} \mathrm{Zn}\left(\mathrm{SO}_{4}\right)_{2} \cdot \mathrm{H}_{2} \mathrm{O}$ & Alfa A13584 & 9665.0 \\
\hline 29 & Descloizite & $\mathrm{PbZn}\left(\mathrm{VO}_{4}\right)(\mathrm{OH})$ & Berg Aukas Mine, Grootfontein District, Namibia & 9666.0 \\
\hline 28 & Legrandite & $\mathrm{Zn}_{2}\left(\mathrm{AsO}_{4}\right)(\mathrm{OH}) \cdot \mathrm{H}_{2} \mathrm{O}$ & Mina Ojuela, Mapimi, Durango, Mexico & 9663.5 \\
\hline 15 & Zinc nitrate hexahydrate & $\mathrm{Zn}\left(\mathrm{NO}_{3}\right)_{2} \cdot 6 \mathrm{H}_{2} \mathrm{O}$ & Acros Organics 211660050 & 9663.5 \\
\hline 19 & Zinc sulfate heptahydrate & $\left(\mathrm{SO}_{4}\right) \mathrm{Zn} \cdot 7 \mathrm{H}_{2} \mathrm{O}$ & Alfa 33399 & 9665.0 \\
\hline
\end{tabular}

mately $9676.5 \mathrm{eV}$ which varies in intensity in the different zinc phosphates.

\subsection{Other zinc minerals and compounds with zinc oxyanions}

Zinc compounds with oxyanions other than phosphate were investigated (Table 4), with spectra shown in Fig. 5. Zinc arsenates are shown separately in Fig. 6 to further illustrate the reproducibility of XANES spectra, regardless of sample location. The zinc arsenates have a nearly identical edge shape and intensity, with divergence only occurring post-edge, around $9680 \mathrm{eV}$.

\subsection{Zinc oxides}

There were four zinc oxide materials used in this study: three naturally occurring minerals - franklinite, gahnite and hetaerolite - and a synthetic zinc oxide compound (Table 5 and Fig. 7).

The spectra for the naturally occurring minerals do not resemble the spectra for zinc oxide. Franklinite more closely

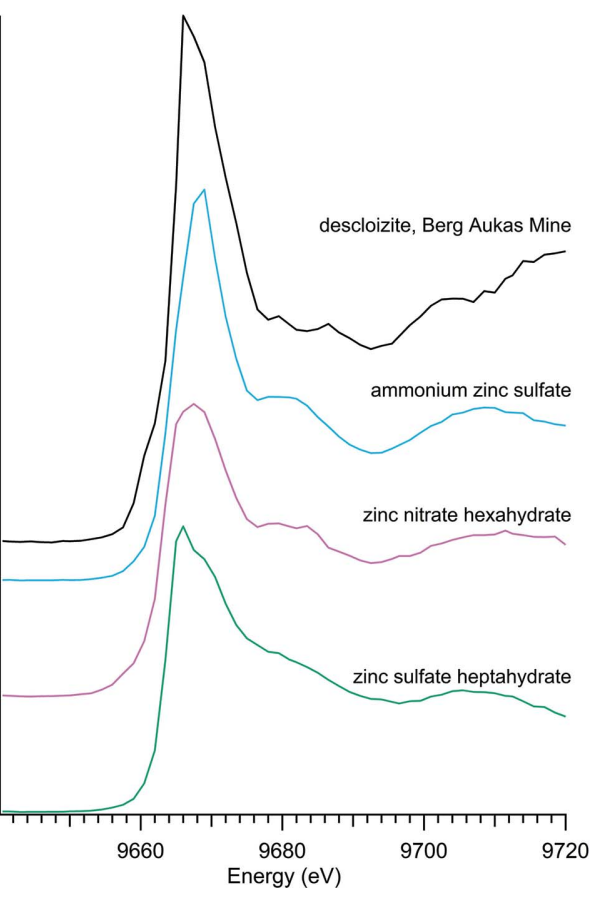

Figure 5

Zinc oxyanion spectra. matches the spectra for hardystonite and willemite, minerals with which franklinite is closely associated in natural environments. A comparison of these spectra is shown in Fig. 8. Although franklinite, dominated by three strong peaks, appears aberrant, it matches well with previously run franklinite $\mathrm{Zn} K$-edge spectra (Waychunas et al., 2003; Hamilton et al., 2016).

There were two samples of hetaerolite, but due to the difficulty of extraction of this mineral there was not enough of the sample from Mohawk Mine to allow for independent verification using the X-ray diffractometer. However, given the similarities of the XAS spectra, and the identical $K$-edge energy, there is a high level of confidence in the identification of the hetaerolite sample from Mohawk Mine.

The zinc oxide sample had one of the lowest observed $K$ edge values. However, the unique shape and low energy level of the zinc $K$-edge may have implications for positively identifying anthropogenic zinc oxides using XANES (Hamilton et al., 2016).

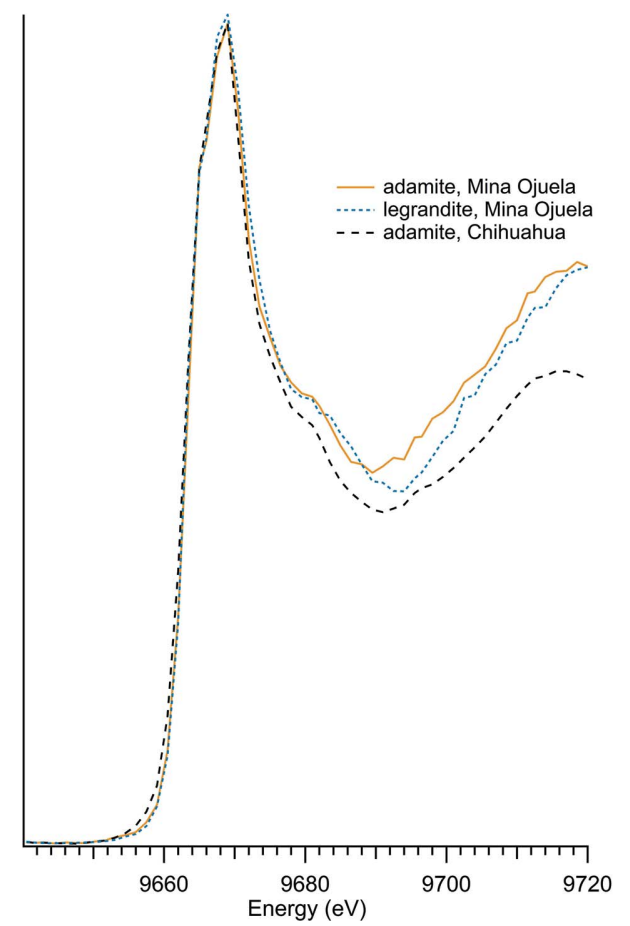

Figure 6

Zinc arsenate spectra. 
Table 5

Zinc oxides.

\begin{tabular}{llllc}
\hline $\begin{array}{l}\text { Sample } \\
\text { number }\end{array}$ & Name & $\begin{array}{l}\text { Ideal chemical } \\
\text { formula }\end{array}$ & Locality & $E_{0}(\mathrm{eV})$ \\
\hline 22 & Franklinite & $\mathrm{ZnFe}_{2} \mathrm{O}_{4}$ & Franklin, NJ, USA, private collection of Ellery Ingall & 9663.5 \\
33 & Gahnite & $\mathrm{ZnAl}_{2} \mathrm{O}_{4}$ & Falun Mine, Falun, Dalarna, Sweden & 9663.5 \\
34 & Hetaerolite & $\mathrm{ZnMn}_{2} \mathrm{O}_{4}$ & Mohawk Mine, San Bernardino County, CA, USA & 9665.0 \\
38 & Hetaerolite & $\mathrm{ZnMn}_{2} \mathrm{O}_{4}$ & Carnahan Mine, Golden, NM, USA & 9665.0 \\
16 & Zinc oxide & $\mathrm{ZnO}$ & CAS 1314-13-2 & 9662.0 \\
\hline
\end{tabular}

\subsection{Organic zinc compounds}

The six organic zinc compounds (Table 6) shared a general spectral shape (Fig. 9), with the significant exception of zinc protoporphyrin, but their peak energy varied more than the other subgroups represented here. For zinc acetate and zinc stearate, the energy peak was shifted to $9665 \mathrm{eV}$, as illustrated in Table 6. The organic zinc samples had a wide main peak, which is most readily observed with the carbonic anhydrase.

The peaks around the $K$-edge of zinc protoporphyrin were closely aligned across all four synchrotron runs; however, the position and intensity of subtle peaks at energies above the $K$-edge were somewhat variable between synchrotron runs for this material.

\subsection{Additional zinc compounds}

Other zinc compounds, which did not fit into the previous categories, include zinc halogens and zinc sulfides (Table 7). There were three samples which contained zinc and sulfur, shown in Fig. 10, and two halogen samples, which included zinc bromide and zinc chloride, illustrated in Fig. 11.

Sphalerite has a strong edge and closely aligned peak, but the sphalerite samples were consistently noisy on the postedge, past about $5 \mathrm{eV}$ from the $K$-edge peak energy. While the presence of iron, visually apparent through the black color of the sphalerite (Hurlbut, 1941), could impact the spectral shape, both sphalerite samples were almost colorless, indicating a very low iron content. This assessment is further

Spectra of zinc oxides.

$$
\text { Energy (eV) }
$$

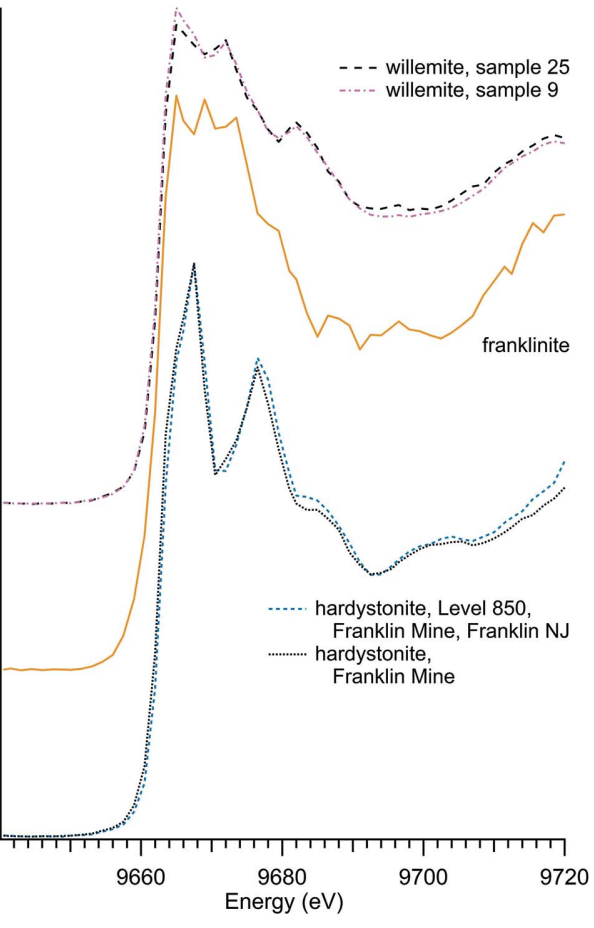

Figure 8

720

Comparison of franklinite specra with zinc silicates.
Figure 9

Spectra of organic zinc.

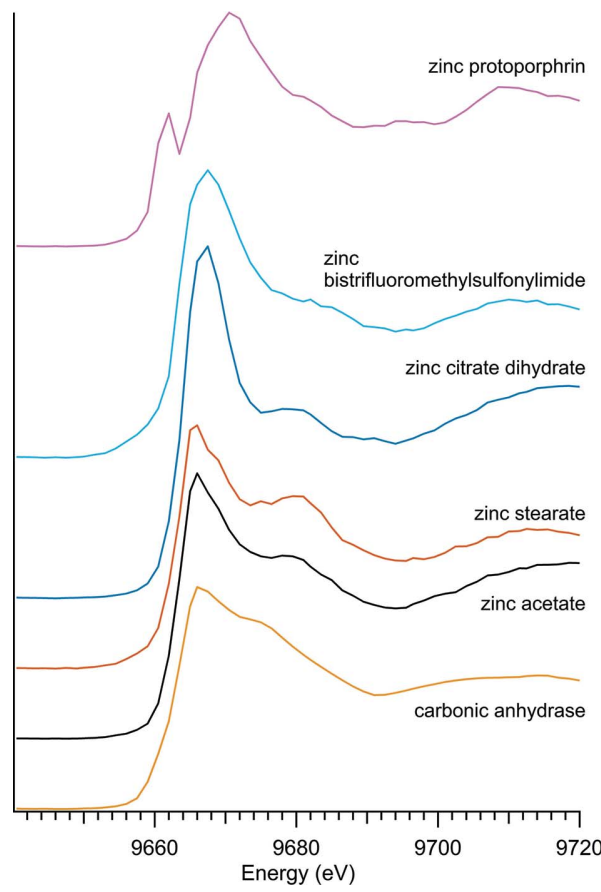


Table 6

Organic zinc samples.

\begin{tabular}{|c|c|c|c|c|}
\hline $\begin{array}{l}\text { Sample } \\
\text { number }\end{array}$ & Name & $\begin{array}{l}\text { Ideal chemical } \\
\text { formula }\end{array}$ & Locality & $E_{0}(\mathrm{eV})$ \\
\hline N/A & Carbonic anhydrase & & MP Biomedicals 153879 & 9665.0 \\
\hline 10 & Zinc acetate & $\mathrm{Zn}\left(\mathrm{CH}_{3} \mathrm{COO}\right)_{2} \cdot 2 \mathrm{H}_{2} \mathrm{O}$ & EM CAS5970-45-6 & 9665.0 \\
\hline 20 & Zinc bis (trifluoromethylsulfonyl)imide & $\mathrm{C}_{4} \mathrm{~F}_{12} \mathrm{~N}_{2} \mathrm{O}_{8} \mathrm{~S}_{4} \mathrm{Zn}$ & Alfa Aesar (chemical formula from \#46880) & 9663.5 \\
\hline 14 & Zinc citrate dihydrate & $\left(\mathrm{C}_{6} \mathrm{H}_{5} \mathrm{O}_{7}\right)_{2} \mathrm{Zn}_{3} \cdot 2 \mathrm{H}_{2} \mathrm{O}$ & Aldrich 480762 & 9663.5 \\
\hline $\mathrm{N} / \mathrm{A}$ & Zinc protoporphyrin, $96 \%$ & $\mathrm{C}_{34} \mathrm{H}_{32} \mathrm{~N}_{4} \mathrm{O}_{4} \mathrm{Zn}$ & Alfa Aesar & 9660.5 \\
\hline 18 & Zinc stearate & $\mathrm{C}_{36} \mathrm{H}_{70} \mathrm{O}_{4} \mathrm{Zn}$ & Alfa 33238 & 9665.0 \\
\hline
\end{tabular}

Table 7

Additional zinc compounds.

\begin{tabular}{llllc}
\hline $\begin{array}{l}\text { Sample } \\
\text { number }\end{array}$ & Name & $\begin{array}{l}\text { Ideal chemical } \\
\text { formula }\end{array}$ & Locality & $E_{0}(\mathrm{eV})$ \\
\hline 7 & Sphalerite & $\mathrm{ZnS}$ & Private collection, unknown location & 9662.0 \\
27 & Sphalerite & $\mathrm{ZnS}$ & Private collection, unknown location & 9662.0 \\
11 & Zinc bromide & $\mathrm{ZnBr}_{2}$ & Acros A0356300 & 9664.0 \\
13 & Zinc chloride & $\mathrm{ZnCl}_{2}$ & Alfa A16281 & 9665.0 \\
23 & Zinc sulfide & $\mathrm{ZnS}$ & Alfa Aesar 40091 & 9662.0 \\
\hline
\end{tabular}

informed by observing the spectra of sphalerite, which is closely matched to the synthetic zinc sulfide.

Both zinc bromide and zinc chloride exhibited a strong peak and a nearly featureless post-edge.

\section{Conclusions}

The consistency of spectral patterns between specimens of the same mineral from different localities suggests that natural compositional variations will not influence identification of these phases in unknown samples. The variety of distinctive

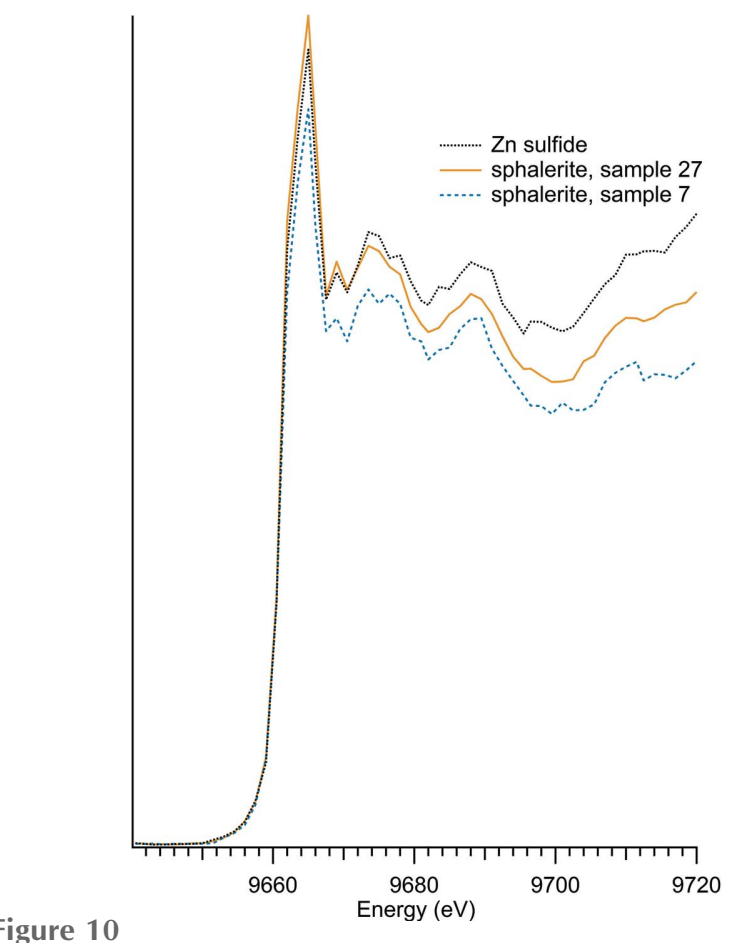

Zinc sulfur spectra. spectra features for the minerals, compounds and organic species will aid in the identification of pure forms of these species and will also be helpful in the application of spectral linear combination approaches for the identification of unknowns in mixtures.

\section{Acknowledgements}

The data used to establish these results is available in the supplementary materials. Any opinions, findings, and conclusions or recommendations expressed in this material are those of the authors and do not necessarily reflect the views of the National Science Foundation.

\section{Funding information}

The following funding is acknowledged: National Science Foundation, Division of Ocean Sciences (grant No. 1357375; grant No. 1658181; grant No. 1658311 to Peter L. Morton); US Department of Energy (contract No. DE-AC02-06CH11357 to

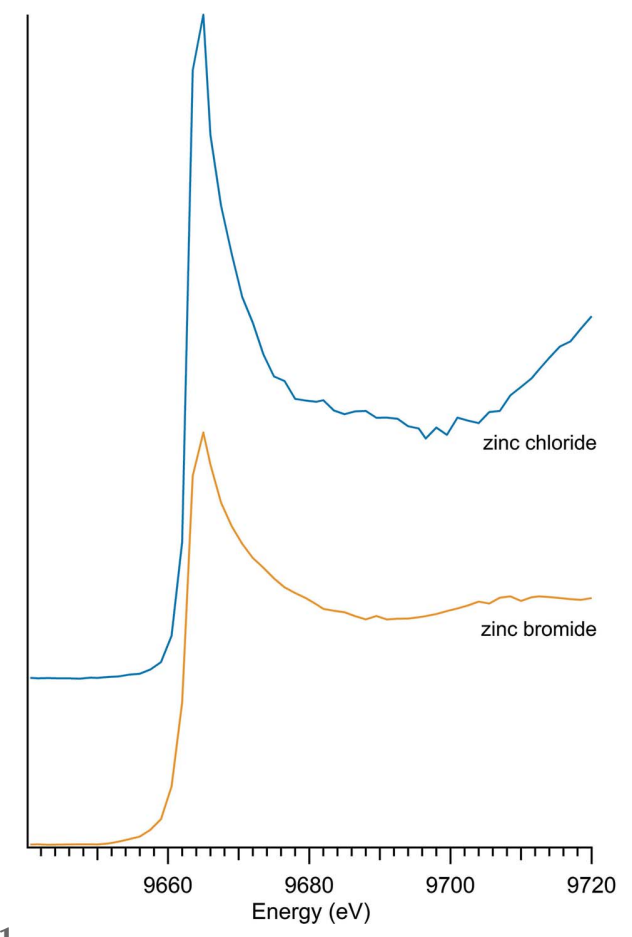

Figure 11

Zinc halogen spectra. 
Barry Lai, Advanced Photon Source at Argonne National Laboratory); National Science Foundation, Division of Electrical, Communications and Cyber Systems (grant No. 1542174 to Georgia Tech Institute for Electronics and Nanotechnology).

\section{References}

Abe, H., Aquilanti, G., Boada, R., Bunker, B., Glatzel, P., Nachtegaal, M. \& Pascarelli, S. (2018). J. Synchrotron Rad. 25, 972-980.

Adediran, G. A., Ngwenya, B. T., Mosselmans, J. F. W., Heal, K. V. \& Harvie, B. A. (2015). J. Hazard. Mater. 283, 490-499.

Bazin, D., Carpentier, X., Brocheriou, I., Dorfmuller, P., Aubert, S., Chappard, C., Thiaudière, D., Reguer, S., Waychunas, G., Jungers, P. \& Daudon, M. (2009). Biochimie, 91, 1294-1300.

Cheng, M., Kopittke, P. M., Wang, A., Sale, P. W. G. \& Tang, C. (2018). Plant Soil, 430, 219-231.

Da Silva-Cadoux, C., Zanella, L. \& Gaillard, J.-F. (2012). J. Anal. At. Spectrom. 27, 957-965.

Dessombz, A., Nguyen, C., Ea, H.-K., Rouzière, S., Foy, E., Hannouche, D., Réguer, S., Picca, F.-E., Thiaudière, D., Lioté, F., Daudon, M. \& Bazin, D. (2013). J. Trace Elem. Med. Biol. 27, 326333.

Doolette, C. L., Read, T. L., Li, C., Scheckel, K. G., Donner, E., Kopittke, P. M., Schjoerring, J. K. \& Lombi, E. (2018). J. Exp. Bot. 69, 4469-4481.

Ellwood, M. J. \& Hunter, K. A. (2000). Limnol. Oceanogr. 45, $1517-$ 1524.

Frenkel, A. I., Hills, C. W. \& Nuzzo, R. G. (2001). J. Phys. Chem. B, 105, 12689-12703.

Gao, J., Zhu, F., Lai, X., Huang, R., Qin, S., Chen, D., Liu, J., Zheng, L. \& Wu, X. (2014). High. Press. Res. 34, 89-99.

Gaur, A., Shrivastava, B. D. \& Joshi, S. K. (2009). J. Phys. Conf. Ser. 190, 012084.

Gervais, C., Thoury, M., Réguer, S., Gueriau, P. \& Mass, J. (2015). Appl. Phys. A, 121, 949-955.

Gräfe, M., Donner, E., Collins, R. N. \& Lombi, E. (2014). Anal. Chim. Acta, 822, 1-22.

Hamilton, J. G., Farrell, R. E., Chen, N., Feng, R., Reid, J. \& Peak, D. (2016). J. Environ. Qual. 45, 684-692.

Hurlbut, C. S. (1941). Dana's Manual of Mineralogy, 15th ed. New York: John Wiley \& Sons.

Ingall, E., Feng, Y., Longo, A., Lai, B., Shelley, R., Landing, W., Morton, P., Nenes, A., Mihalopoulos, N., Violaki, K., Gao, Y., Sahai, S. \& Castorina, E. (2018). Atmosphere 9, 201.

Isaure, M. P., Manceau, A., Geoffroy, N., Laboudigue, A., Tamura, N. \& Marcus, M. A. (2005). Geochim. Cosmochim. Acta, 69, 11731198.
Jacquat, O., Voegelin, A. \& Kretzschmar, R. (2009). Geochim. Cosmochim. Acta, 73, 5256-5272.

Leinweber, P., Kruse, J., Walley, F. L., Gillespie, A., Eckhardt, K.-U., Blyth, R. \& Regier, T. (2007). J. Synchrotron Rad. 14, 500-511.

Le Pape, P., Quantin, C., Morin, G., Jouvin, D., Kieffer, I., Proux, O., Ghanbaja, J. \& Ayrault, S. (2014). Environ. Sci. Technol. 48, 1190111909.

Longo, A. F., Ingall, E. D., Diaz, J. M., Oakes, M., King, L. E., Nenes, A., Mihalopoulos, N., Violaki, K., Avila, A., Benitez-Nelson, C. R., Brandes, J., McNulty, I. \& Vine, D. J. (2014). Geophys. Res. Lett. 41, 4043-4049.

Löscher, B. M. (1999). Mar. Chem. 67, 67-102.

Malviya, S., Scalco, E., Audic, S., Vincent, F., Veluchamy, A., Poulain, J., Wincker, P., Iudicone, D., de Vargas, C., Bittner, L., Zingone, A. \& Bowler, C. (2016). Proc. Natl Acad. Sci. USA, 113, E1516-E1525.

Mamindy-Pajany, Y., Sayen, S., Mosselmans, J. F. W. \& Guillon, E. (2014). Environ. Sci. Technol. 48, 7237-7244.

Manceau, A., Marcus, M. \& Tamura, N. (2002). Rev. Mineral. Geochem. 49, 341-428.

Monsant, A. C., Kappen, P., Wang, Y., Pigram, P. J., Baker, A. J. M. \& Tang, C. (2011). Plant Soil, 348, 167-183.

Oakes, M., Weber, R. J., Lai, B., Russell, A. \& Ingall, E. D. (2012). Atmos. Chem. Phys. 12, 745-756.

Ravel, B. \& Newville, M. (2005). J. Synchrotron Rad. 12, 537-541.

Rivera, N., Hesterberg, D., Kaur, N. \& Duckworth, O. W. (2017). Energy Fuels, 31, 9652-9659.

Rouff, A. A., Eaton, T. T. \& Lanzirotti, A. (2013). Chemosphere, 93, 2159-2164.

Sarret, G., Balesdent, J., Bouziri, L., Garnier, J.-M., Marcus, M. A., Geoffroy, N., Panfili, F. \& Manceau, A. (2004). Environ. Sci. Technol. 38, 2792-2801.

Sunda, W. G. \& Huntsman, S. A. (2005). Limnol. Oceanogr. 50, 11811192.

Tella, M., Bravin, M. N., Thuriès, L., Cazevieille, P., Chevassus-Rosset, C., Collin, B., Chaurand, P., Legros, S. \& Doelsch, E. (2016). Environ. Pollut. 212, 299-306.

Wang, L., Lu, X. \& Huang, Y. (2013). X-ray Spectrom. 42, 423428.

Wang, Y., Li, A., Zhan, Y., Wei, L., Li, Y., Zhang, G., Xie, Y., Zhang, J., Zhang, Y. \& Shan, Z. (2007). J. Radioanal. Nucl. Chem. 273, $247-$ 251.

Waychunas, G. A., Fuller, C. C., Davis, J. A. \& Rehr, J. J. (2003). Geochim. Cosmochim. Acta, 67, 1031-1043.

Webb, S. \& Gaillard, J.-F. (2015). Aquat. Geochem. 21, 295-312.

Yamamoto, K. \& Hashimoto, Y. (2017). J. Environ. Qual. 46, 461465.

Zhou, D., Jia, H., Rana, J., Placke, T., Scherb, T., Kloepsch, R., Schumacher, G., Winter, M. \& Banhart, J. (2017). Electrochim. Acta, 246, 699-706. 